\title{
Impact of Foreign Direct Investment on Trade of African Countries
}

\author{
Zenegnaw Abiy Hailu \\ Shanghai University of Finance and Economics \\ North Zhongshan No. 1 Road, 200083, Shanghai, China \\ E-mail: zenegnaw@gmail.com
}

\begin{abstract}
It is not uncommon to see African countries struggling to address their foreign currency shortage. FDI is presumed to play a role in addressing this problem. With this in mind, the main objective of the study is to determine the relationship between FDI and trade balance (import and export) of African countries for the period 1980 to 2007. Due to data heterogeneity, non-continuity and because the Hausman test favours it over the Random Effect technique, the Least Square Dummy Variable (LSDV) regression method is used. The elasticities of both export and import are positive and significant with larger elasticities noted for exports relative to imports. This implies that Multi-National Enterprises (MNEs) in SSA are not just export-oriented but also import dependent. To save on the scarce foreign reserve, investment policy makers in those countries should direct MNEs towards those areas involving further export promotion, import substitution and local factor intensive investments.
\end{abstract}

Keywords: Foreign Direct Investment (FDI), African countries, Export, Import

\section{Introduction}

Foreign Direct Investment (FDI) is a potent instrument of economic development, especially for the less developed countries. It enables capital-poor countries, like most African countries, to build up physical capital, create employment opportunities, develop productive capacity, enhance skills of local labour through transfer of technology and managerial know-how, and help integrate the domestic economy with the global economy. In integrating the local economy with the global economy, it affects the Balance of Payment (BoP) of countries.

The inflow of FDI plays an important role in determining the surplus/deficit in the capital and financial account of the BoP statement. It can be said that the initial impact of an inflow of FDI on BOP is positive but the medium term direct effect could become either positive or negative as investors increase their export output, imports of intermediate goods and services, and begin to repatriate profits. For that matter, one can even question the role of FDI on economic growth. FDI flows may have a negative effect on the growth prospects of a country if they give rise to substantial reversal flows in the form of remittance of profits and dividends and/or if the Multi-National Enterprises (MNEs) obtain substantial tax or other concessions from the host country. These negative effects could be compounded if the expected positive spill-over effects from the transfer of technology are minimized because the technology transferred is inappropriate for the host country's factor proportion or as a result of overly restrictive intellectual property right.

After setting up capital machineries, the FDI-financed companies begin to export their products as most of these companies are export-oriented. FDI-financed firms may tend to export a greater proportion of their output than their local counterparts as these firms usually have a comparative advantage in their knowledge of international markets, efficiency of distribution channels, and their ability to adjust and respond to the changing pattern and dynamics of international markets.

After all, one may ask, why are we concerned about the trade balance? The current account balance is an important indicator of any economy's performance and it plays several roles in policy makers' analysis of economic developments. First, its significance stems from the fact that the current account balance, reflecting the saving-investment ratio, is closely related to the status of the fiscal balance and private savings which are key factors of economic growth. Second, a country's balance on current account includes the difference between its exports and imports, reflecting the totality of domestic residents' transactions with foreigners in markets for goods and services. Third, since the current account balance determines the evolution over time of a country's stock of net claims on the rest of the world, it reflects the inter-temporal decisions of (domestic and foreign) residents. Therefore, policy makers are trying to explain the current account balance movement, assess their optimal level, and seek to induce changes to the balance through policy measures. There are three sub-accounts under the current account, namely balance of trade, investment income and unilateral transfer. For most countries, trade balance is the major component of the current account. Trade balance is the difference between 
export and import of a country for a specified time period, usually a year. It is the main component of the current account balance of a country. Determinants of trade flows have always attracted researchers in both academic area and policy-making institutions as they are the main determinants of the current account balance and eventually the economic performance of a country.

\section{Backgrounds of the study}

Now, let's see the nature of BoP, current account balance and its components for African countries in relation to the rest of the world. Figure 1 shows the BoP and its components of Sub-Saharan Africa for the period 1980-2007. Only less than one-third of the periods have shown a positive change in reserve of the Sub-Saharan Africa whilst the remaining years have shown negative changes. This deficit should be financed either by running positive current account balance or capital and financial account balance. Unfortunately, the current account balance too is negative for most years. Trade balance too is, as a main component of this account, predominantly negative for the entire period. This would indicate that those countries require either capital (both private domestic and foreign) and/or international monetary flow. One form of capital flow is FDI. As these countries are destinations of foreign investment, the net investment income of the region is always negative for the study period. That depletes the already scarce foreign reserves of those countries. The only sub-account of this category with mainly positive balance is net-transfer. These countries rely too much on aid, donation and other unilateral transfers to narrow the deficit. Those forms of financing are not reliable in a sense that there is no guarantee as to their continuity. The net transfer itself is not high enough to close the gap requiring additional means of financing, usually leaving these countries highly soaked in debt.

To adjust this deficit FDI is presumed to play a significant role through different channels. One of the mechanisms is through its effect on import and export. As can be seen from Figure 1 FDI flow to African countries is increasing over time. Export and import too are growing at exponential rate (Figure 2) over time as that of FDI. For that matter the growth rate of export and import is faster than that of FDI growth. For possible reasons cited in the literature review, FDI may contribute to the increase of these two macroeconomic variables. Two questions are imminent in relation to the relationship among these variables; to what extent does FDI affect import and export? And what is the net effect of FDI on the trade balance of those countries?

With this in mind, this study tries to see the effect of FDI on trade balance of African countries using econometric methods. Regression techniques are employed to see the effect of FDI on export, import and finally overall trade balance. The paper is organized as follow; the next section deals with literature review on the interplay of the two economic variables. The third section covers the econometric analysis. Results are interpreted in the fourth section and finally, conclusions are drawn and recommendations are forwarded in the last chapter.

\section{Literature review}

\subsection{Previous studies}

Numerous studies have been conducted on the issue of factors determining trade balance, both taking itself as a subject of study or by breaking down to its components, namely import and export. Alternative theories have different predictions about the factors underlying balance of trade dynamics and about the sign and magnitude of the relationship between trade balance fluctuations and the determinants.

Theoretical studies have shown that international trade and investment are complementary rather than substitutes if trade between two economies is based on their comparative advantages. However, if the trade between the two countries is based on their absolute advantages, there may be substitution between trade and investment, as businesses decide to supply products and services through exports or FDI. The degree of complementarity between trade and investment therefore remains an empirical question. Some studies, like (Culem (1988); Ozawa (1992); Ruggiero (1996); Ethier and Horn (1990); Wei, et al. (1999)) appears to predict that international trade and investment are complements, as firms take advantage of factor price differences through cross-border vertical production integration. Others, like (Brainard, 1997; Brouthers, et al. 1996; Goldberg and Klein, 1997).), on the contrary, suggest that greater transaction costs resulting from higher trade barriers and transportation cost, lead to horizontal cross- border production expansion and thus, stimulate international investment. In this view, international trade is more or less a substitute for international investment. Similarly, international factor mobility including FDI may substitute and hence reduce trade in goods. Mundell (1957) argued that commodity movements are at least to some extent a substitute for factor movements. According to him, an increase in trade barriers stimulates factor movements and an increase in restrictions to factor movements stimulates trade. 
This complementarity or substitutability may result in positive or negative relationship between trade and FDI. According to Aizenman and Noy (2005) and Culem (1988), there is a bidirectional linkage between FDI and trade. They suggested that there is a strong feedback type of relationship between FDI flows and trade, especially in manufacturing goods.

With different motivations, FDI has a different effect on trade. Motivations can be classified into two general categories: market-seeking and factor-seeking (Root 1994). Market-seeking FDI follows demand, penetrating foreign markets with promising sales potential. Market-seeking FDI may have a negative impact on the host country's trade balance since the affiliates of foreign firms (in the US), according to a study on US (Graham and Krugman 1989), show an apparent tendency to export somewhat less and import significantly more than US firms--indeed over two and a quarter times as much. Factor-seeking FDI includes MNEs behaviour aimed at gaining access to raw materials and low-cost locations. FDI motivated by the quest for raw materials is used to produce goods with natural resources that are lacking or under-supplied in the home country. In general, this type of FDI increases exports from the host nation to the home country, as well as to other third countries (Root 1994). FDI motivated by low-cost production objectives takes advantage of low-cost factors, such as cheap labour, as part of an overall global sourcing strategy, leading to an ability to export products from the emerging host nation to other countries in the world, including the MNEs' home countries. In this case, the host country is able to increase exports and to improve

its trade balance (Phongpaichit, 1990)

In the business and economic approaches to FDI, trade is considered to be one of the factors that determine the MNE's choice of location for FDI initiatives. On the one hand, a high level of imports in host countries suggests a high level of penetration by foreign companies, which may start off by exporting to the host country, to subsequently switch to FDI once they have established a foothold in those countries. Following this logic, a positive relationship is hypothesized between host-country import and inward FDI (Culem 1988). On the other hand, in the short run, MNEs may regard export and FDI as alternative modes of foreign market penetration, which implies a negative relationship. Therefore, there is uncertainty as to the net effect of the level of the host country's imports on FDI and vice versa (Billington 1999).

A related literature investigates the relation of trade and FDI in the context of development issues. Based on the conceptual framework developed by Porter (1990), Ozawa (1992) formulated a comprehensive theory describing linkages between economic development and competitiveness that create international trade and FDI. Ozawa argues that an increase in trade flows occurs as a result of improved comparative advantage, which, in turn, is influenced by FDI.

Different empirical researches have come up with different conclusions on the relationship of FDI and foreign trade. To the best knowledge of the author, there is hardly any panel study on FDI-trade nexus for African countries. There are studies on other countries and blocks of countries in this regard. For instance, Zhang and Song (2000), find support for the widely held belief that increased levels of FDI positively affect export performance for China. Using an augmented export demand model and a panel data set for 11 Organization for Economic Cooperation and Development (OECD) countries Pain and Wakelin (1998) find that inward FDI has a positive effect on export. Other studies too indicated that FDI actually has a positive effect on export performance of host countries (Cabral, 1995; Blake and Pain, 1994). A study that identified factors affecting India's export performance (Sharma, 2003) indicates FDI has statistically no significant impact on export performance although its coefficient has a positive sign. On the contrary, using trade equations for the US and Swedish firm-level data, Blomstrom, et al. (1988) find that the relationship between FDI and export sales is complementary, hence a negative relationship exists. Several cross-country studies found support for the hypothesis of a negative relationship between FDI and export (Jeon 1992). There still are the middle grounders who find no significant relationship between FDI and trade

Studies on import-FDI relationship are not as common as that of export-FDI. Even some authors take trade as a synonym for export. Studies, like Culem (1988) identified existence of long run positive relationship between host country import and FDI inflow.

\subsection{Theoretical framework}

\subsubsection{Export and FDI}

FDI and international trade are not only increasingly complementary and mutually supportive, but also increasingly inseparable as two sides of the process of economic globalization (Ruggiero 1996). Furthermore, inward FDI may stimulate exports from domestic sectors through industrial linkage or spill-over effects, 
especially through backward linkages, buying local-made intermediate inputs to produce exports (Haddad \& Harrison, 1993). This effect creates a strong demand stimulus for domestic enterprises and promotes exports.

FDI is expected to affect export from the export supply side of the host country. FDI may enhance export-oriented productivity that further improves export performance. Others may argue that export leads to increase in productivity that further attracts foreign investors to undertake FDIs. Export contributes to growth by facilitating labour mobilization and capital accumulation. In theory, there is a two-way causal relationship between trade and productivity, although advocates of export-led growth generally contend that exports enhance productivity growth. These economists argue that firms tend to learn advanced technologies through exports and must adopt them to compete in the foreign marketplace. Firms also learn by doing, and emulate foreign rivals through trial and error inherent in the production and sale of export goods.

Furthermore, the expansion in production resulting from exports reduces unit production prices, thus increasing productivity. In addition to these effects, exports also provide a country with foreign exchange, which is often scarce in the early stages of economic development, enabling a country to import capital and intermediate goods. Thus, for a variety of reasons, exports increase productivity growth. The reverse causation from productivity growth to exports is also intuitively straightforward. Productivity growth improves a country's international competitiveness in price and quality, and thereby boosts its exports.

\subsubsection{Import and FDI}

Studies on the effect of FDI on import are scant. FDI both at the initial investment and operation phases can influence import of a country. At the initial investment phase, import of equipments, machineries, installation facilities and experts all contribute to increased import balance. FDI companies have high propensities to import capital and intermediate goods and services that are not readily available in the host country.

In the later phases of the investment; input nature, output type, productivity spill-over and type of relationship with other role players in the industry determine the direction of effect of FDI on import of a country. If FDI uses local raw materials and other inputs of production, it may not have significant adverse effect on import. On the contrary, if it relies on imported inputs like raw material, human skill, and other intangibles assets, it affects import positively. The relationship between import and output type of FDI can be positive or negative. If the output is complementary to other products that are imported, it may encourage import and would have positive effect. However, if FDI is concentrated in import substituting industries, then it is expected to affect imports negatively because the goods that were imported earlier would now be produced in the host country by foreign investors.

The effect of productivity of FDI and spill-over from FDI on import can be seen together. The theoretical relationship between imports and productivity, and hence FDI, is more complicated than that of exports and productivity. Increased imports of consumer products encourage domestic import-substituting firms to innovate and restructure themselves in order to compete with foreign rivals; therefore, imports enhance productive efficiency. It can also attract foreign firms to undertake investment activities to supply the market. These MNEs, with their experience in supplying both the foreign market and the potential host countries' market previously, are better suited to mobilize factors of production to the host country and engage in production. If that is the case, imports would be discouraged because of domestic supply from MNEs' production facilities. By the same logic, with the positive technological, human capital and other spill-over from foreign firms to local firms, domestic firms could contribute further to the import substitution effect leading to decreased import.

Another channel of FDI effect is dependent on the kind of relationship with different levels of the value chain in the industry. In a forward integration, an FDI may be engaged in further processing of a partially processed output of a local company that used to be exported for further processing in a foreign company. This production process may render the product extra quality that makes it usable at the local market. That would have a negative effect on import and export. In a backward integration, an FDI may undertake production of an item, which is an input for another production facility. If that intermediate product was an import item, such kind of integration would have a negative effect on import. With all these possible directions of outcomes, FDI may have positive or negative effect on trade balance.

\section{Methods of data collection and analysis}

In an open economy exports are assumed to be a function of: (i) income in the rest of the world; (ii) the price of a country's goods relative to those produced by competitors abroad; and (iii) other factors such as tastes, quality of the goods, delivery dates and so on. The third category is difficult to measure for empirical studies but proxies can be used to see their effect. Deliver date can be proxied by infrastructure condition of the country. Reliable 
and efficient infrastructure facilities are essential for reducing costs, ensuring timely supply of exports and thereby improving export performance (Srinivasan, 1998). However, many developing countries including most African countries lack reliable and efficient infrastructure facilities. This contributes to higher costs and poor export performance. Thus, we expect a positive link between improved infrastructure facilities and export supply.

Imports are assumed to be determined by the same factors as that of exports (since one country's exports are another country's imports) with the exception that the income variable relevant to imports is domestic income. As domestic income rises, ceteris paribus, aggregate demand will increase and some portion of this increase in demand will be met by imported goods; that is, the marginal propensity to import is greater than zero.

Both the import and export functions are usually stated in terms of volume but for this study, the total amount to GDP ratio will be used instead. This is because, the objective of the study is not to measure the performance of the export subsector as such but rather to see the foreign reserve earning potentials of factors, particularly FDI, which is a function of total amount not volume. Import and export functions for particular sectors of the economy would have given a better insight into the interplay between FDI and the trade variables; however, due to the problem with data availability with sectorial breakdown, total export and import amounts are used. The common formulation of these relationships is in the form of simultaneous equation of export/import (domestic) supply and export/import (foreign) demand functions. In this paper, however we use a linear regression equation of the overall export/import amount as a ratio of GDP to the aforementioned variables since the objective of this paper is to determine the relationship between these variables and export/import rather than deriving an equilibrium level.

This study examines the relationship between export/import performance and FDI flows across African countries for the period from 1980 through 2007. Export to GDP ratio, import to GDP ratio and then trade balance to GDP ratio of those countries are modelled as a function of FDI/GDP and other explanatory variables.

A dynamic model type is formulated:

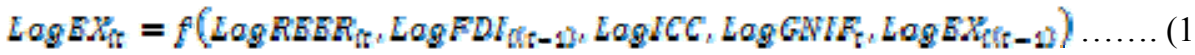

$$
\begin{aligned}
& (-) \quad(?) \quad(+) \quad(+) \quad(+)
\end{aligned}
$$

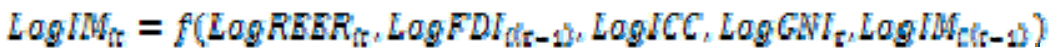

$$
\begin{aligned}
& (+) \quad(?) \quad(+) \quad(+) \quad(+)
\end{aligned}
$$

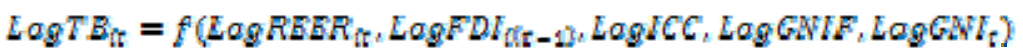

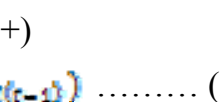

Where:

$\mathrm{EX}_{\mathrm{tt}}-$ Export to GDP ratio of country $\mathrm{i}$ in year $\mathrm{t}$

$\mathrm{EX}_{1(\mathrm{t}-1)}-$ Export to GDP ratio of country $\mathrm{i}$ in year $\mathrm{t}-1$ or the one year lagged value of export to GDP ratio.

$\mathbb{R H E R}_{\mathrm{tt}}$ - Real effective exchange rate index $(2000=100)$ of country $i$, for year $\mathrm{t}$;

$\mathrm{FDI}_{\mathrm{It}}$ - Foreign Direct Investment stock to GDP ratio of country i, for year $\mathrm{t}$

GNIF: $_{\mathrm{t}}$ - World income, proxied by the Gross National Income per capital of the World in US\$ at year $\mathrm{t}$.

$\mathrm{ICC}_{\mathrm{It}}$ - Infrastructure condition of country $\mathrm{i}$, for year $\mathrm{t}$ as proxied by number of mobile phone and fixed line phone per 1000 population

$I W_{\mathbb{t}}$ - Import of goods and service as a ratio of GDP for country $\mathrm{i}$, in year $\mathrm{t}$

$1 \mathrm{M}_{1 \mathrm{i} t-1 \mathrm{y})}$ - Import to GDP ratio of country $\mathrm{i}$ in year $\mathrm{t}-1$ or the one year lagged value of import to GDP ratio.

$\operatorname{GNT}_{\tilde{t} \mathrm{t}}$ - Gross National income per capital of country $\mathrm{i}$, in year $\mathrm{t}$

$T B_{\tilde{t r}}$ - Trade balance to GDP ratio of country i, for year $\mathrm{t}$

Note: The trade balance formulation is included to give a complete set of equation but since the majority of African countries have recorded a negative trade balance for longer time and logarithm of a negative value is undefined, running regression is impossible. The elasticity effects of factors on balance of trade would be approximated from partial coefficients of the independent variables from the import and export regression output. The regression output for the trade balance formulation is presented on Appendix B. The reported number of observation is less than $1 / 3$ of the total observation in the data set due to the fact that negative values are excluded from analysis. 
Studies by Khan and Ross (1977) and Salas (1982) suggest that in modeling an aggregate demand function, the $\log$-linear specification is preferable to the linear formulation. Therefore, the log specification is used instead of

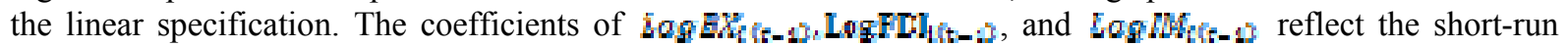
elasticity of exports with respect to each of these variables. The value of the coefficient on $L Q g F D I_{V:-1\}}$ is of particular interest for this study, as this coefficient indicates the impact of FDI in previous year on the export and import performance in the next year.

The lag structure of the model is to capture the relatively longer time period, which may be required for the impacts of FDI to be felt on export performance. The effects of FDI on export performance are not likely to be felt immediately because modernizations of production facilities, dissemination of new production technologies, or other changes require time to take effect. The lagged value of exports/import is included on the right hand side of the model because of the significant relationships between past and future export performance. This procedure is commonly used in economic analyses where there may be a strong tendency for past economic trends to influence future performance (Coughlin \& Cartwright, 1987) hence included as independent variable in both export and import specification.

Data used for this study are collected from World Development Indicators, World Bank, online source (Note 1). Annual data from African counties, namely: Burundi, Cameron, Cote d'Ivore, Gabon, Gambia, Ghana, Lesotho, Malawi, Morocco, Nigeria, Sierra Leone, South Africa, Tunisia, Togo, Uganda and Zambia is collected for the period between 1980 and 2007. Study subject selection is dictated solely by data availability among African nations. For descriptive statistics of the raw data you may refer to Table 1. The nominal import and export amount as a percentage of GDP is used for this analysis as the ratio takes care of the price level difference.

Due to the wide gap in macroeconomic indicators of the region, hence data heterogeneity, other regression techniques would give better result than the Ordinary Least Square method. Least Square Dummy Variable (LSDV) and Random Effect Methods (REM) are alternatives under the situation. Hausman test is performed to choose from the two and Fixed Effect (FE) model is found to give superior result than the random effect. In addition to that, the objective of the study is to determine the effect of the factors under consideration on African countries, not to explain the inter-country difference. This makes FE more desirable than the RE. Following the works of (reference-model) fixed cross-section effect Fixed Effect - Ordinary Least Square (FE-OLS) regression method is applied to determine the significance of the effect of the explanatory variables on the dependent variables.

\section{Empirical Results}

\subsection{Export determinants}

All the variables, as can be seen on Table 2, show their expected sign. It is well known that the appreciation of the real effective exchange rate (REER) reduces export (Joshi \& Little, 1994; Srinivasan, 1998) hence, a negative link between the appreciation of REER and export demand is expected. The negative coefficient of REER for the regression output implies that the real appreciation of the local currency adversely affects the country's exports. Converse, the real depreciation of local currency helps the export subsector. This is in line with both theoretical reasoning in international finance and findings of previous empirical studies (Cushman, 1983; Caballaro and Corbo 1989; Lastrapes and Koray 1990). A one point decrease in REER results in a 0.00014 per cent increase in exports. Though the coefficient is small, the effect is statistically significant at 95 per cent confidence interval. This implies that REER targeting may help the export subsector of the economy.

The lagged value of FDI/GDP has a positive effect on export and it is statistically significant. The coefficient of LogFDI/GDP indicates that a 1 per cent increase in FDI in the previous year brings about 0.043 per cent increases in export of the next period. This elasticity coefficient is significant for African countries implying that FDI has important contribution to the export subsector of the continent. Expanding FDI in the region will have a positive effect for export promotion and subsequently to the trade balance.

As has been expected, infrastructure condition of the exporting country plays a positive role in promoting export but the effect is statistically insignificant. A unit increase in the infrastructure proxy, distribution of 1 more mobile and fixed line telephone per 1000 population, increases export per GDP by $0.002 \%$. This small effect is also insignificant in statistical terms indicating that the contribution of infrastructure development to export growth is small for the study subjects.

Another factor expected to have positive effect on export growth rate is income growth rate of the world. Unlike the finding of previous studies like (Srinivasan, 1998), based on the income elasticity of export per GDP is only $0.018 \%$ and it is statistically insignificant. The insignificant effect can be seen from two possible angles; African 
exporters do not respond to either higher demand or lower prices. If the former is the case, as the world income increase, demand for African exports may increase too but if African exporters cannot increase capacity to supply the additional demand, world income may not be significant factor for export promotion. Policy makers may address this problem by supporting capacity building efforts of export oriented FDIs through provision of loan facilities, lifting bureaucratic hurdles for expansion and so on. If the latter is the case, African exports are for subsistence purpose hence export may not decline even with a persistence price decrease due to fall in demand. In the second scenario, export diversification may address the problem. Export from Africa are characterized by both reliance on primary products and capacity under-utilization hence both the above factors can play roles on the insignificant income elasticity of export.

The positive and significant coefficient on $\operatorname{LogEX} \mathrm{X}_{(\mathrm{t}-1)}$ suggests that previous export performance is positively associated with the export performance during the next year. Its value of .52 implies than a 1 per cent change in the level of exports in previous year is associated with 0.52 per cent increase in exports in the next year. This high and significant elasticity imply the structural reliance of those countries on export over time (persistence effect).

\subsection{Import determinants}

When we see the output of the import equation, REER is found to have negative impact on import growth while the other variables have positive impact on imports (Table 3). Import also has significant elasticity for the lagged value of FDI. The lagged import growth rate has positive and significant effect on import growth rate. Both infrastructure condition and domestic income level have positive but insignificant effect on import growth.

The negative coefficient of REER indicates that real appreciation of local currency leads to decrease in rate of import. This is not in line with the theoretical basis of international finance. For that matter, the effect is statistically significant. A unit decrease in REER (real depreciation) leads to a 0.0001 per cent increase in import. This may be explained by the nature of import items. African countries import items of "strategic" nature like pharmaceuticals, energy, and others that are price inelastic by nature. If this is the case, without any change in import quantity and with higher price, the total import amount will be higher showing inverse relationship between REER and import/GDP.

The relationship between FDI and import is also found out to be positive. The positive and significant coefficient on $\operatorname{LogFDI}(t-1)$ suggests that previous period's FDI is positively associated with the import performance during the next year. The coefficient value of 0.032 implies than a 1 per cent change in the level of exports in previous year is associated with 0.032 per cent increase in imports in the next year. Different explanations can be forwarded. One reason could be, FDIs, rather than engaging in import substitution activities, they are involved in import of inputs of production. Another explanation may be that FDIs focus on production of goods or services that are complementary to other import products that increase the import of the complementary product/service. Investment policy makers have a lee-way to address these problems. Encouraging FDIs that are local input -intensive, introduction of technologies that use available inputs of production, encouragement of the domestic sector to engage in production and supply of inputs of productions that would have been imported by FDIs and the likes may help.

Infrastructure condition of those countries is found to have insignificant effects on import performance of those countries. The insignificant effect may imply that import demand is irresponsive to the level of development of the infrastructure facilities as imports of those countries may not require that developed infrastructure.

Domestic income level, as measured by GNI growth rate has a positive effect on export growth of the countries but the effect is statistically insignificant. The insignificant income elasticity may be explained by the fact that for the majority of the countries, the population lives in poverty so the increase income may not be high enough to shift consumption from domestically produced to imported goods/services.

The positive and significant coefficient on $\operatorname{LogIM}(t-1)$ suggests that previous import performance is positively associated with the import performance during the next year. Its value of 0.95 implies than a 1 per cent change in the level of exports in previous year is associated with 0.95 per cent increase in exports in the next year. This high elasticity value indicated the strong structural reliance on import from time to time.

\subsection{Trade balance determinants}

The analysis of the trade balance determinants is based on the partial elasticity coefficients of the dependent variables of both the export and import equation. Simple regression formulation is ruled out as the value of trade balance for most countries and for longer time frame is negative and logarithm of negative values is undefined. An effort to regress LogTB to possible determinant factors shows exclusion of the majority of observations with 
negative values for the dependent variable and the independent variables. The results of the regression are presented on Appendix A for reference purpose but no inference can be made on the result. Any factor that affects import positively will have a negative effect on trade balance and vice versa. From the export side, any factor with a positive effect on export growth rate will have a positive effect on balance of trade. Therefore, we will see the determinant factors by taking the net effects of export and import. The weight of import from the total trade is 85.24 per cent and that of export is 14.76 per cent for the period. This implies that the effect of a factor on import will have greater weight and stronger effect on overall balance of trade.

REER is a negative force on balance of trade from export side and a positive force from import side (TB = EX IM, hence). The partial effect coefficients of REER are -0.00014 and -0.00011 for export and import growth functions respectively. So the net partial effect of REER is positive, indicating that real appreciation of local currency has an increasing impact on the balance of trade of African countries. As has been stated above, this can be explained by the more than proportional share of import on the total trade of the countries and hence effect of import growth on trade balance, than that of the effect of export. This indicates that REER targeting may not be a good means of adjusting the trade balance of those countries.

The partial elasticity of export to FDI is higher than that of import but the net effect will be negative on balance of trade as the weight of export on total trade is far lower than that of import. A 1 per cent increase in FDI brings about 0.043266 per cent increase in export and 0.031987 per cent increase in import. The net elasticity of balance of trade to FDI will be negative due to the weight effect. To address this problem, promotion of export oriented FDI and import substituting ones will increase the relative share of export in the total trade amount.

Infrastructure condition too will have a negative impact on growth rate of trade balance, the net coefficient will be negative. This means an increase in infrastructure condition of a country, results in a decrease in trade balance growth rate. Just as that of FDI, the result should not be interpreted as it is, this is so because infrastructure condition facilitates total trade (both export and import) but due to the higher share of import in trade, the negative impact outweighs the positive effect. Increasing the share of export on the total trade allow reaping the positive effect of infrastructure on balance of trade.

The other two variables, since they affect trade performance from one side, will take their sign and elasticity value in their export and import regression equations. The elasticity of balance of trade per GDP is 0.018 per cent for per capital income of the world and 0.002968 percent for domestic income level.

\section{Conclusions and Recommendations}

Over the past few decades Africa's import and export has grown fast. Several factors appear to have contributed to this phenomenon including FDI. However, to date there has not been that much attempt to investigate the role of FDI on trade. Using panel data for the period 1980-2007 for 16 African countries, this issue is investigated.

REER has negative and significant effects on both import and export. It means that when the local currency appreciates in real terms, both import and export growth rate will decrease. The inverse relationship between export performance and REER is in line with both theory and empirical works but that of import and REER is not intuitive. This can be explained by the nature of import items. African countries import items of "strategic" nature like pharmaceuticals, energy, and others that are price inelastic by nature. If this is the case, without any change in import quantity and with higher price, the total import amount will be higher showing inverse relationship between REER and import/GDP.

The positive and significant FDI elasticity of export implies that FDI has important contribution to the export subsector of the continent. Expanding FDI in the region will have a positive effect for export promotion and subsequently to the trade balance. For the FDI-import nexus different explanations can be forwarded. One reason could be MNEs, rather than engaging in import substitution activities, are involved in import of inputs of production. African countries lag behind in terms of human capital development and technological progress. This necessitates reliance on imported inputs of production by MNEs. Another explanation may be that FDIs focus on production of goods or services that are complementary to other import products that increase the import of the complementary product/service. Investment policy makers have a lee-way to address these problems. Encouraging FDIs that are local input-intensive, introduction of technologies that use available inputs of production, encouragement of the domestic sector to engage in production and supply of inputs of productions that would have been imported by MNEs and the likes may help.

When we see the overall effect of FDI on balance of trade, if a factor has positive effect on both import and export, the net effect on balance of trade is found to be in the direction of effect on the import. This is due to the very high share of import on the total trade of those countries. Countries in the early stage of development, like 
most African countries, would benefit more from export than import as the country would probably fall short of foreign currency. Hence, in this regard, investment policy instruments should be in place to assure that investment (both foreign and domestic) in areas of export promotions and import substitutions are encouraged.

Infrastructure condition of the countries under investigation is not a significant factor affecting both import and export. The insignificant effect may imply that export supply and import demand are unresponsive to the level of development of the infrastructure facilities as export and import of those countries may not require highly developed infrastructure.

Both import and export are income inelastic. The insignificant effect of the World income growth on export performance can be seen from two possible angles; either African exporters are not responsive to higher demand or they are unresponsive to lower prices. If the former is the case, as the world income increase, demand for African exports may increase too but if African exporters cannot increase capacity to supply the additional demand, world income may not be a significant factor for export promotion. Policy makers may address this problem by supporting capacity building efforts of export oriented FDIs through provision of loan facilities, lifting bureaucratic hurdles for expansion and so on. If the latter is the case, African exports are for subsistence purpose hence export can not be cut even with a persistence price decrease due to fall in demand and export diversification may address the problem. The unresponsiveness of import to domestic income growth level may indicate that, for the majority of the countries, the population lives in poverty so the increase income is not be high enough to shift consumption from domestically produced to imported goods/services

In general, policy makers in African countries have the opportunity to influence their inflow of foreign reserve in the promotion of export oriented MNEs and manage their scarce foreign reserve by controlling import oriented MNEs. FDI having a positive effect on export; putting economic, social and political instruments that contribute to the motivate MNEs engagement helps those countries to earn foreign reserves. FDI also increase import and investment policy makers in those countries should direct FDI to areas that are none import-intensive so as to economize on the scarce foreign reserve in the region.

\section{References}

Aizenman, J. and I. Noy. (2005). "FDI and trade - two-way linkages?" National Bureau of Economic Research Working Paper Series No. 11403. Cambridge, Massachusetts.

Billington, N. (1999). The location of foreign direct investment: an empirical analysis. Applied Economics 31(1), 65-76.

Blake, A., and N. Pain. (1994). "Investigating Structural Change in U.K. Export Performance: the role of innovation and direct investment", National Institute of Economic and Social Research (NIESR) Discussion Paper No. 71.

Blomstrom, M., Lipsey, R.E. and Kulchycky, K. (1988). 'U.S. and Swedish Direct Investment and Exports'. In Baldwin, R. E. (Ed.) Trade Policy Issues and Empirical Analysis. Chicago: University of Chicago Press.

Brainard S. L. (1997) "An empirical assessment of the proximity-concentration trade-off between multinational sales and trade" The American Economic Review 87(4), 520-544.

Brouthers, L.E., Werner, S. and Wilkinson, T.J. (1996). 'The Aggregate Impact of Firms' FDI Strategies on the Trade Balance of Host Countries'. Journal of International Business Studies, 27(2), 359-373.

Caballero, R.J. and Corbo, V. (1989). "The effects of real exchange rate uncertainty on exports: Empirical evidence", The World Bank Economic Review, 3(2), 263-278.

Cabral, L. (1995). “Sunk Costs, Firm Size and Firm Growth”, Journal of Industrial Economics 43(2), 161-172

Coughlin, C. C. \& Cartwright, P. A. (1987). “An examination of state foreign export promotion and manufacturing exports". Journal of Regional Science, 27 (3), 439-449.

Culem, C.G. (1988). 'The Locational Determinants of Direct Investment among Industrialized Countries'. European Economic Review, 32(4), 885-904.

Cushman, D.O. (1983). "The effects of real exchange rate risk on international trade", Journal of International Economics, 15(1-2), 45-63.

Ethier, W. J. and Henrik H. (1990). "Managerial Control of International Firms and Patterns of Direct Investment", Journal of International Economics, 28(1-2), 25-45.

Goldberg, L.S. and Klein, M.W. (1997). 'Foreign Direct Investment, Trade and Real Exchange Linkages in Southeast Asia and Latin America'. National Bureau of Economics Research Working Paper, 6344. 
Graham, E.M. and P. Krugman. (1989). Foreign Direct Investment in the United States, Institute for International Economics, Washington, DC.

Haddad, M., \& Harrison, A. (1993). Are there positive spillovers from direct foreign investment? Journal of Development Economics, 42(1), 51-74.

Jeon, Y. (1992). The Determinants of Korean Foreign Direct Investment in Manufacturing Industries, Weltwirtschaftliches Archiv 128(3), 527-541.

Joshi, V. \& Little, I. M. D. (1994). India: Macroeconomics and Political Economy 1964-1991.Washington, DC: World Bank.

Khan, M. S. and K. Z. Ross. (1977). The Functional Form of the Aggregate Import Equation, Journal of International Economics, 7,149-60.

Lastrapes, W. and Koray, F. (1990). Exchange rate volatility and U.S. multilateral trade Flows, Journal of Macroeconomics, 12(3), 134-48.

Mundell, R. (1957). International Trade and Factor Mobility. American Economic Review, 47, 321-335.

Ozawa, T. (1992).Foreign Direct Investment and Economic Development. Transnational Corporation, 1, 27-54.

Pain, N., and K. Wakelin (1998). Export Performance and the Role of Foreign Direct Investment. The Manchester School Supplement 66, 62-88.

Phongpaichit, P. (1990). 'The New Wave of Japanese Investment in Asia. Singapore: Institute of Southeast Asian Studies.

Porter, M. E. (1990). "The competitive advantage of nations" Boston MA: Macmillan.

Root, F. (1994). ‘Entry Strategies for International Markets. New York, MacMillan.

Ruggiero, R. (1996). Foreign Direct Investment and the Multinational Trade System. Transnational Corporation, $5,1-18$

Salas, J. (1982). Estimation of the Structure and Elasticities of Mexican Imports in the Period 1961-1979, Journal of Development Economics, 10,297-311.

Sharma, K. (2003). Factor's Determining India's Export Performance, Journal of Asian Economics, 14 (3), 435-446.

Srinivasan, T. N. (1998). India's export performance: A comparative analysis. In I. J. Ahluwalia \& I.M.D. Little (Eds.), India's economic reforms and development essay for Manmohan Singh. Delhi: Oxford University Press.

Umo, Joe U. and Tayo Fakiyesi. (1995). "Profiles and Determinants of Nigeria's Balance of Payments: The Current Account Component (1950-88)", AERC Research Paper No.40.

Wei, Y., Liu, X., Parker, D. and Vaidya, K. (1999). “The Regional Distribution of Foreign Direct Investment in China" Regional Studies, 33, 857-867

Zhang and Song. (2000). "Promoting Export, The Role of Inward FDI in China" China Economic Review 11, 385-396.

\section{Notes}

Note 1. World Development Indicators Online (WDI) provides direct access to more than 800 development indicators, with time series for 209 countries and 18 country groups from 1960 to now, where data are available, http://ddp-ext.worldbank.org/ext, date accessed October 12, 2009 
Table 1. Descriptive statistics of the raw data

\begin{tabular}{|l|c|c|c|c|c|c|c|c|}
\hline & EX & FDI & GNIF & GNIG & ICC & IM & REER & TB \\
\hline Mean & 0.31655 & 0.26293 & 5619.65900 & 1991.59200 & 6.26682 & 1.82833 & 151.55880 & -0.29356 \\
\hline Median & 0.28656 & 0.17624 & 5289.72100 & 950.00000 & 0.86391 & 0.02035 & 111.17290 & -0.00033 \\
\hline Maximum & 3.54920 & 1.27449 & 9950.3100 & 12320.0000 & 97.87109 & 274.94630 & 3870.10900 & 7.49089 \\
\hline Minimum & 0.04091 & 0.00005 & 2755.79400 & 210.000000 & 0.04693 & 0.00008 & 51.18917 & -57.80299 \\
\hline Std. Dev. & 0.21357 & 0.25262 & 1944.84700 & 2589.82500 & 14.39593 & 16.57870 & 239.22460 & 2.95779 \\
\hline Skewness & 8.27903 & 1.42749 & 0.50381 & 2.25863 & 3.92951 & 13.59297 & 11.11648 & -17.58720 \\
\hline Kurtosis & 124.92600 & 4.92036 & 2.37323 & 7.24063 & 20.00483 & 203.24890 & 151.24290 & 339.58670 \\
\hline Jarque-Bera & 267475.3 & 218.02870 & 26.28565 & 713.38840 & 6375.1970 & 721483.9 & 419445.1 & 2023325.0 \\
\hline Probability & 0.00000 & 0.00000 & 0.0000 & 0.0000 & 0.0000 & 0.00000 & 0.00000 & 0.00000 \\
\hline Sum & 134.21610 & 116.21550 & 2517607.0 & 888250.0 & 2732.332 & 775.2107 & 67898.33 & -124.4682 \\
\hline Sum Sq. Dev. & 19.29297 & 28.14511 & $1.69 \mathrm{E}+09$ & $2.98 \mathrm{E}+09$ & 90150.60 & 116262.9 & 25581094 & 3700.6320 \\
\hline Observations & 424 & 442 & 448 & 446 & 436 & 424 & 448 & 424 \\
\hline
\end{tabular}

Table 2. Export regression result for African Countries

\begin{tabular}{|c|c|c|}
\hline \multirow[t]{2}{*}{ Independent Variables } & \multicolumn{2}{|c|}{ LSDV/FE-OLS } \\
\hline & Coeff. & St. Err. \\
\hline $\mathrm{C}$ & -0.68004 & 0.55700 \\
\hline REER & $-0.00014 * *$ & 0.00006 \\
\hline $\operatorname{LogFDI}_{(t-1)}$ & $0.04327 * *$ & 0.01936 \\
\hline ICC & 0.00208 & 0.00156 \\
\hline LogGNIF & 0.01800 & 0.06250 \\
\hline $\operatorname{LogE} X_{(t-1)}$ & $0.52091 * * *$ & 0.04315 \\
\hline $\mathbf{R}^{2}$ & \multicolumn{2}{|c|}{$81.52 \%$} \\
\hline $\mathbf{N}$ & \multicolumn{2}{|c|}{382} \\
\hline
\end{tabular}

Table 3. Import regression results for African countries

\begin{tabular}{|c|c|c|}
\hline \multirow[t]{2}{*}{ Independent Variables } & \multicolumn{2}{|c|}{ LSDV/FE-OLS } \\
\hline & Coeff. & St. Err. \\
\hline $\mathrm{C}$ & -0.28199 & 0.64329 \\
\hline REER & $-0.00011 * *$ & 0.00006 \\
\hline $\operatorname{LogFDI}_{(t-1)}$ & 0.03199* & 0.01796 \\
\hline ICC & 0.00182 & 0.00151 \\
\hline LogGNI & 0.00297 & 0.09081 \\
\hline $\log I M_{(t-1)}$ & $0.95047 * * *$ & 0.01003 \\
\hline $\mathbf{R}^{2}$ & \multicolumn{2}{|c|}{$99.44 \%$} \\
\hline $\mathbf{N}$ & \multicolumn{2}{|c|}{381} \\
\hline
\end{tabular}


Appendixes A: Balance of Trade results for African countries

\begin{tabular}{|c|c|c|}
\hline \multirow[t]{2}{*}{ Independent Variables } & \multicolumn{2}{|c|}{ LSDV/FE-OLS } \\
\hline & Coeff. & St. Err. \\
\hline $\mathrm{C}$ & 2.00558 & 8.41600 \\
\hline REER & -0.00120 & 0.00106 \\
\hline $\operatorname{LogFDI}_{(t-1)}$ & -0.15441 & 0.16744 \\
\hline ICC & 0.00504 & 0.01378 \\
\hline LogGNIF & 0.40091 & 0.61950 \\
\hline LogGNI & -1.00355 & 1.23968 \\
\hline $\log E X_{(t-1)}$ & 0.53698 & 0.55735 \\
\hline $\operatorname{LogI} M_{(t-1)}$ & $0.87236^{* * *}$ & 0.12125 \\
\hline $\mathbf{R}^{2}$ & \multicolumn{2}{|c|}{$87.09 \%$} \\
\hline $\mathbf{N}$ & \multicolumn{2}{|c|}{111} \\
\hline
\end{tabular}

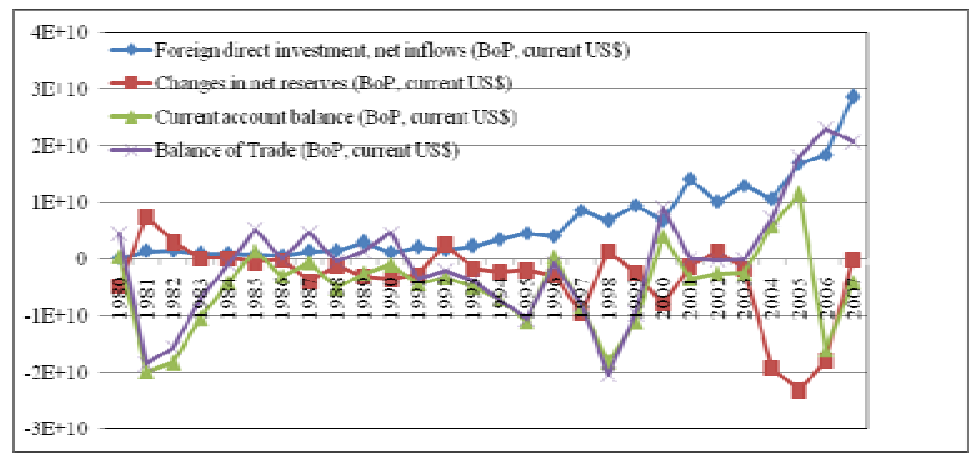

Figure 1. Current account and FDI in SSA for the period 1980-2007 (Data source: World Development Indicators, World Bank)

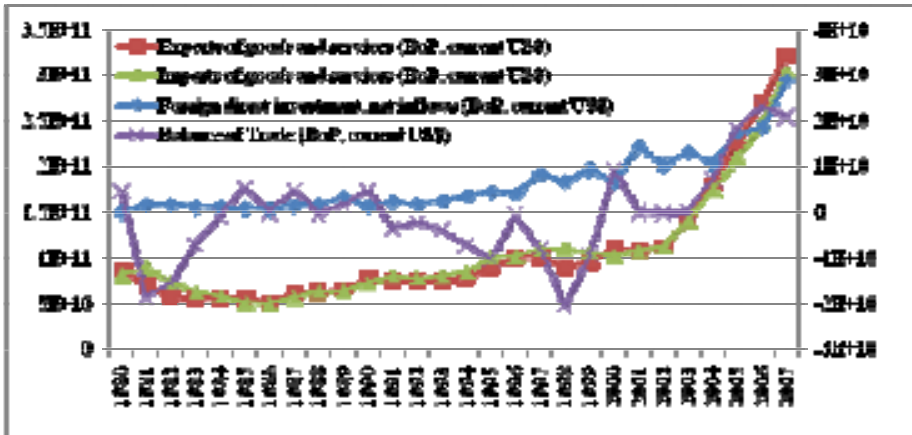

Figure 2. Trade balance and FDI in SSA for the period 1980-2006 (Data source: World Development Indicators, World Bank) 